\title{
THE LEGAL FRAMEWORKS THAT GOVERN ELECTRONIC ARBITRATION PROCESSES AND ITS ROLE IN RESOLVING INTERNATIONAL
}

\section{TRADING CONTRACTS DISPUTES}

\author{
ASAM SAUD S ALSAIAT \\ Member of Faculty of Sharia and Law, Aljouf University, Kingdom of Saudi Arabia \\ Researcher in Law, School of Law, Essex University, United Kingdom
}

\begin{abstract}
The electronic contract is governed by the general rules and provisions that are governed by the general theory of the contract. It is agreed between the parties to the contract, but it is characterized as a telecommuting contract between absentees using electronic media. There is no doubt that these characteristics that characterize the electronic contract influence their legal system and make it have some special rules.

It is known that the normal way to resolve all disputes is the formal judiciary. The national legislation for the resolution of international disputes has established rules called international jurisdiction, but in the face of the many problems faced by the judiciary in solving the disputes of international electronic commerce, a new institution called Electronic Arbitration has been able to provide solutions for a range of problems that were floundering.

This study aims to study the legal framework regulating electronic arbitration and its role in resolving international trading contracts disputes by exploring previous studies and international laws on this subject.

KEYWORDS: Electronic Arbitration, Legal Framework \& Jurisdiction
\end{abstract}

Received: Mar 27, 2018; Accepted: Apr 17, 2018; Published: May 18, 2018; Paper Id.: IJPSLIRJUN20181

\section{INTRODUCTION}

The Internet is a global revolution in the modern era, which is similar to the Industrial Revolution. It offers its customers many possibilities, such as shopping, advertising and contracting without the need for mobility or physical presence.

Due to the increasing use of the Internet in various fields of life, the number of disputes arising from these uses, especially in electronic commerce in light of the establishment and registration of websites for companies and merchants through the internet, and the increasing number of dealers in electronic commerce, in addition to the accompanying contracts on the internet, and delays in delivery and payment, resulting in many disputes requiring speedy resolution away from the regional and local judicial bodies, as the recourse to justice places a heavy burden on contractors in this area (Fayad \& Kazzi, 2015).

In the absence of effectiveness and failure to keep pace with the normal arbitration of the required speed in the completion of electronic transactions, electronic arbitration emerged as a modern method to resolve disputes arising as a result of the use of the Internet in transactions, especially electronic, where electronic arbitration responds to the characteristics of the electronic commerce environment and constitutes a solution to the many 
obstacles raised by applicable law, the competent court and so on.

Accordingly, several websites were established to help resolve disputes through electronic arbitration, most notably the World Intellectual Property Organization (WIPO). The electronic sales sites have been contracted with WIPO to solve disputes that may arise between them and their customers because of the many advantages of electronic arbitration (Ben-Shimsa, 2009).

E-arbitration is very similar to conventional arbitration, and it differs only in the way it is done. The idea of electronic arbitration is to rely on modern means of communication, without the need for the personal presence of opponents and arbitrators in one place or the physical transfer from one place to another (BAERT, 2016; Ahemd, 2018).

The subject of the research faces the fundamental problem of the extent of the ability of electronic arbitration to solve the disputes of e-commerce. This leads primarily to the question of what this judiciary and its characteristics which make it distinct from other methods of resolving trade disputes. It also raises questions about the legal frameworks that govern it, as well as its role in resolving electronic disputes.

\section{RESEARCH OBJECTIVES}

The main objective of this research is to:

\section{Study the Legal Frameworks that Govern Electronic Arbitration Processes and its}

\section{Role in Resolving International Trading Contracts Disputes}

This main aim is divided into sub-objectives:

- Study the legal framework regulating electronic arbitration in the light of international conventions, comparative laws, and electronic arbitration centers.

- Clarify the electronic arbitration agreement through arbitration procedures, ending with the arbitration decision and its implementation.

- Identify the advantages and disadvantages of electronic arbitration.

\section{RESEARCH SIGNIFICANCE}

The importance of the study stems from the reflection of the tremendous development in the world of communications and information technology on the completion of transactions in record periods, where disputes may arise between the parties, which requires the creation of modern means suitable for the nature of online business, which has advantages that are lacking in the courts and even traditional alternative means of resolving disputes.

\section{ELECTRONIC ARBITRATION AND ITS EFFECTIVENESS}

E-arbitration is any arbitration conducted through the Internet or any other electronic means to resolve electronic disputes So that the dispute will be presented and followed in its proceedings and the decision will be issued and communicated electronically. It is a mixture of rules and conditions for dispute solutions, which, although based on the traditional arbitral environment, but it has undoubtedly generated new rules and norms that have created a kind of independence for a new type of arbitration (Wahab, 2012). 
The laws and conventions governing traditional arbitration are, of course, insufficient to meet the challenges posed by the use of technology in the arbitration process, which is difficult to ignore. It is therefore, necessary to amend the conventions and laws related to arbitration and to devise appropriate mechanisms to give it legitimacy and enforceability; arbitration is not an end in itself, but a means of resolving the dispute (Fayad \& Kazzi, 2015).

Electronic arbitration provides many advantages to the parties, which derive mainly from the nature of the medium in which the arbitration process takes place (the internet). However, as with any modern system, certain advantages and disadvantages are taken.

Electronic arbitration is a great service in bridging distances. Most of the disputes of electronic commerce take place between parties of different nationalities and their residence places. In this regard, it is suggested that alternative means of settling disputes over the Internet, in particular, electronic arbitration, will help settle disputes in the various geographically isolated areas where parties cannot travel or meet (Hörnle, 2002).

With the growth of electronic commerce, where millions of small transactions are concluded between merchants and customers, which are often less than traditional arbitrage costs, electronic arbitration reduces the costs associated with the arbitration process (Gilliéron, 2007).

Electronic arbitration is far superior to traditional arbitration in the speed of adjudication of disputes. Traditional arbitration requires much longer than electronic arbitration requires. As well as, The rapid increase in the volume of electronic commerce has resulted in an increase in the volume and frequency of disputes, which are often subject to different legal systems due to the nature of the international business processes of the Internet, resulting in a conflict of laws and jurisdiction which is difficult to resolve; for different rules of attribution from one country to another. The role of electronic arbitration is reflected in enabling the parties to avoid this difficult and uncertain outcome, where the parties agree on the applicable law, either the subject matter of the dispute or the proceedings in an explicit manner or by referring to a specific arbitration center.

Unlike traditional courts or arbitral tribunals, electronic arbitration is available 24 hours a day. This feature enables parties to send e-mails or contact at any time without having to incur the trouble of traveling.

On the other hand, one of the main obstacles to electronic arbitration lies in the existence of the digital divide between countries, but also within the developed countries themselves. People living in remote and rural areas often do not have an adequate level of telecommunications to reach the packages required for the effective use of the Internet for these types of services, affecting the right to confront, listen and respond to the offers of the other party, which has an impact on integrity Evidence thus deprives a fair trial. This is in addition to language barriers, as a few electronic arbitration centers pay sufficient attention to the problem of cultural and linguistic differences.

\section{INTERNATIONAL TRADING CONTRACTS DISPUTES}

Commercial contracts concluded through the Internet are either commercial contracts for both parties (Business to Business) (B2B) or contracts of a hybrid commercial nature, i.e. commercial to one party and civilian to the other (Consumer to Business) (B2C). 
B2B Trading contracts are the most common forms of electronic commerce and are important in terms of financial impact, and the growth rate of this sector is expected to continue to record. Disputes arising out of B2B are divided into four types of contracts, as follows (Ben-Shimsa, 2009):

- Contracts related to electronic commerce infrastructure: This type of contract includes contracts for communication services and operation of the Internet service. These contracts fall under the terms of the interconnection agreements, and between companies that are authorized to establish the internet infrastructure, companies and institutions wishing to benefit from this service in providing services to others. Disputes arising out of this type of contract are one of the most complex types of disputes because of the legal issues related to the interpretation and modification of the contract because of the need for a change in its conditions to counter the developments of the same technology. On the other hand, many countries of the world allocate ICT regulators to interfere with the conclusion and implementation of such contracts, especially since such contracts often affect the internal public order of the State, whether in the areas of national security or in the areas of antitrust or unfair competition laws Or licenses for the provision of telecommunications services, as well as problems related to foreign investment in developing countries (Neacsu, 2016).

- Contracts between ISPs and licensed companies: This type of contract raises disputes related to the price of communication services, terms of service, as well as the responsibility of service providers for the security of information in transit.

- Contracts between commercial establishments that used the Internet: There is no doubt that this type of contract has significantly changed the traditional methods of offering goods and services. It raises many disputes of a contractual nature, such as cost, compliance with the terms of agreements between companies, as well as disputes of a non-contractual nature, Legitimate or trade secrets and information security.

- Contracts of a closed nature: Most disputes arising from such types of contracts are contractual disputes, such as those that arise in the area of traditional commerce, such as the difference in price, type of goods, quantity or delivery date.

\section{ELECTRONIC ARBITRATION SOURCES AND RULES}

Although electronic arbitration is an extension of traditional arbitration and differs only in terms of means, its legitimacy derives not only with the agreement of the parties. It is also necessary to combine the efforts of international and regional organizations, whether economic or academic, on the one hand, in addition to the intervention of national legislation and international conventions to ensure the integrity of the ruling issued and the mechanism issued by them on the other hand.

Perhaps the most prominent role in the emergence of electronic arbitration refers to electronic arbitration centers, where academic attempts represented in the Faculty of Law at the University of Montreal contributed to the experience in the emergence of cyber tribunal, and the World Intellectual Property Organization (WIPO) played a major role in the development and activation of the electronic arbitration system.

Many legal systems have contributed to the establishment and elaboration of electronic arbitration provisions, most notably the European directives and model laws on e-commerce, such as European Union Directive No. 31/2000 on 
Electronic Commerce. Article 34 of this Directive stated that each Member State shall amend its legislation, which includes the specific conditions and requirements, which are likely to be used to limit contracts concluded by electronic means; consideration of such legislation requiring such a settlement must be regular and should include all necessary work and stages of the contractual process. As well as, article 37 provided that the Member States must remove obstacles and legal impediments to the use of electronic contracts (Directive\& Provisions, 2000).

UNCITRAL Model Law on International Commercial Arbitration aims to assist States in reforming and modernizing their laws on arbitral proceedings to take account of the particular features and needs of international commercial arbitration. The law covers all stages of the arbitration process, beginning with the arbitration agreement, the composition and jurisdiction of the arbitral tribunal, and the scope of the court's intervention through recognition and enforcement of the arbitral award. The law reflects a global consensus on the main aspects of international arbitration practices, accepted by States from all regions and from different legal or economic systems of the world (Patocchi, 2016).

The great role played by the World Intellectual Property Organization (WIPO) has also contributed significantly to the development and activation of the electronic commerce arbitration system to regulate internet disputes, particularly intellectual property, domain names and trademarks, so it can overcome many difficulties.

WIPO allows for the freedom to choose the applicable law, including the penalty unit, despite the different nationalities. The issue of resolving trade disputes related to intellectual property rights very quickly and inexpensively, and the provision of alternative solutions to long-term which costly judicial processes are very vital. The need for this has emerged in recent years as the importance of e-commerce contracts has increased, and the Arbitration and Mediation Center at WIPO offers great help in resolving the conflicts mentioned for individuals and companies in every corner of the world (UNCTAD, 2014).

WIPO has a long list of the best experts and rulers in this field from about 70 countries. These countries are subject to the laws of WIPO in conflict resolution methods and often use these methods in countries in every language and law and create an atmosphere of change and flexibility. WIPO's methods are particularly advantageous for companies that avoid costly and long-term litigation, particularly at the international level.

\section{LEGAL FRAMEWORKS OF E-ARBITRATION}

The electronic settlement centers gradually use mechanisms for resolving international trade disputes. For example, the re-settlement center communicates between the parties and negotiates between the parties to the dispute to reach a certain settlement within a specified period. If the period ends without reaching a settlement of the dispute, arbitration will take place.

Legal opinions were agreed on the validity of the electronic arbitration agreement, which was written electronically, and were based on the need to expand the concept of writing to include electronic writing in addition to traditional writing. They also relied on explicit texts contained in national and international e-transactions, as in the Model Law on Electronic Commerce on December 1996, the United Nations Convention on the Use of Electronic Communications in 2005, the Federal Electronic Transactions and Commerce Act No. 1 of 2006, and the Emirate of Dubai Law No. 2 of 2002 (Al-Ra'I, 2010). 
Electronic arbitration is subject to two types of legislative frameworks and legal systems. There are general frameworks and regulations that represent the general law of international commercial arbitration. Thus, electronic arbitration must be consistent with these general provisions contained in international and regional treaties and conventions.

In addition to the general legislative framework, electronic arbitration is also subject to a special legislative framework specifically designed for the electronic environment and for this type of arbitration. This type of special framework is in the laws on electronic commerce as in the UNCITRAL Model Law on Electronic Commerce and the UNCITRAL Model Law on Electronic Signatures (United Nations Commission on International Trade Law, 2007), and the United Nations Convention on the Use of Electronic Communications in International Contracts of 23 November 2005 , as well as the various electronic arbitration rules, In the Canadian Cyber Tribunal, the American Arbitration Association, whose rules have been set up for electronic arbitration, and electronic dispute resolution procedures between trademarks and electronic sites and the intention of the World Intellectual Property Organization (WIPO) (Al-Ra'I, 2010).

The request for electronic arbitration is an electronic communication issued by the plaintiff by e-mail to the other party, or the electronic arbitration institution referring the dispute between them to the agreed arbitration court, stating that the arbitral proceedings are on their way to commence. The submission of an electronic arbitration request differs from traditional arbitration application from the fact that the application is made electronically by the Internet site designated by the Arbitration Center for the dispute in question.

If the traditional arbitral institutions had acted in favor of the parties in the case of the agreement on a particular language, the arbitral awards of the electronic arbitral tribunals appeared different in that regard. The interpretation of this is that, with respect to the Cyber Tribunal, extensive powers have been given to the arbitral tribunal in determining the language used in arbitration at the expense of the parties' will.

Accordingly, Article 12 of these Regulations provides that the arbitral tribunal shall determine the language or languages of the arbitration proceeding, taking into account the terms of the contract, including the language of the contract. It is clear from the text that it is the arbitral tribunal that determines the language used during arbitration proceedings. The text required the Commission to take into account the terms of the contract in question, in particular, the language in which it was written (Hart, 1999).

If it is not clear to the electronic arbitral proceedings before the Electronic Space Court, this is clearly evident in the supplementary procedures for the electronic arbitration of the American Arbitration Association (AAA). The interpretation of this is that article 8 of these procedures provides that unless the parties agree otherwise, the language of arbitration shall be the language of the document or documents containing the arbitration agreement unless otherwise decided by the arbitrator (Colvin, 2011).

\section{CONCLUSIONS}

Electronic arbitration is characterized by speed in resolving disputes and this is compatible with the nature of electronic trading. Since litigation procedures are relatively long in which many formalities and time limits must be observed by the litigants and the reason for saving time is due to the fact that electronic arbitration does not require the transfer of the parties to the dispute or their physical presence before the arbitrators, but the parties can be heard through the electronic media. At the same time, opponents can exchange evidence and documents by e-mail or other electronic 
means.

The existence of an international convention on the recognition and enforcement of arbitrators, the New York Convention of 1958, avoids parties wishing to be arbitrarily subject to conflict of law and jurisdiction, since contracts concluded through the Internet in general and electronic commerce contracts in particular, are international contracts that do not specify a particular geography. The network is open globally and has its own territory.

The parties, particularly the weaker party in the contract, are concerned about resorting to arbitration in general and electronic arbitration in particular because of the fear that the protectionist rules provided in their national law will not apply, especially if that party is a consumer.

Electronic arbitration, which was recently developed and is still in the process of modernization and legal and technical regulation, still requires the intervention of international organizations and States to develop a comprehensive framework to achieve the universality of recognition and regulation of this new type of arbitration.

\section{REFERENCES}

1. Fayad, M., \&Kazzi, H. (2015). ELECTRONIC ARBITRATION IN LEBANON-OVERVIEW AND TRENDS. European Scientific Journal, ESJ, 11(7).

2. Ahmed, Adnan (2018). Challenges of Electronic Arbitration in Electronic Commerce transactions, MECS Journal, 2(2).

3. Wahab, M. S. A. (2012). ODR and e-Arbitration-Trends \& Challenges. Online Dispute Resolution Theory and Practice, International Eleven Publishing.

4. Ben-Shimsa, R. (2009). Legal Framework for Electronic Arbitration "A Comparative Study", An-Najah National University, College of Graduate Studies.

5. Baert, P. R. (2016). The Potential of Online Arbitration (OARB) in Resolving Disputes at the Lower End of Value.

6. Hörnle, J. (2002). Online Dispute Resolution-The Emperor's New Clothes: Benefits and Pitfalls of Online Dispute Resolution and its Application to Commercial Arbitration. ADR Online Monthly.

7. Gilliéron, P. (2007). From face-to-face to screen-to-screen: real hope or true fallacy. Ohio St. J. on Disp. Resol., $23,301$.

8. Neacsu, N. A. (2016). Consumer protection in electronic commerce. Bulletin of the Transilvania University of Brasov. Economic Sciences. Series V, 9(1), 301.

9. DIRECTIVE, H. A. T., \& PROVISIONS, G. (2000). Council Directive 2000/43/EC of 29 June 2000 implementing the principle of equal treatment between persons irrespective of racial or ethnic origin. Official Journal L, 180(19/07), 0022-0026.

10. Patocchi, P. M. (2016). UNCITRAL Model Law on International Commercial Arbitration 1985 with amendments as adopted in 2006. United Nations Publication.

11. UNCTAD, W. (2014). United Nations conference on trade and development. Review of Maritime Transport.

12. Ibrahim, Saalah Yakubu. "The Middle-East Crisis and the United Nations (UN) Effort in Resolving It: An Overview."

13. Colvin, A. J. (2011). An empirical study of employment arbitration: Case outcomes and processes. Journal of Empirical Legal Studies, 8(1), 1-23.

14. Al-Ra'i, Rose (2010). Legal System of Electronic Arbitration in Electronic Commerce: Comparative Study, International Trade and Investment Law. 
15. Hanumanthappa, D. G. "Constitutional and legal provisions for women in India." International Journal of Multidisciplinary Research and Development 2.8 (2015): 474-476.

16. United Nations Commission on International Trade Law. (2007). United Nations Convention on the Use of Electronic Communications in International Contracts. United Nations Publications.

17. Hart, C. (1999, August). Online dispute resolution and avoidance in electronic commerce. In Uniform Law Conference of Canada. August. 